\title{
SIGNIFICANCE OF PAP SMEAR IN DETECTING ABNORMALITIES OF CERVIX IN HIV-INFECTED WOMEN
}

\author{
M. Kavitha1, T. Pavithra'2, C. Lalitha ${ }^{3}$
}

${ }_{1}^{1}$ Assistant Professor, Department of Pathology, Coimbatore Medical College, Tamilnadu.

${ }^{2}$ Assistant Professor, Department of Pathology, Coimbatore Medical College, Tamilnadu.

3Professor, Department of Pathology, Coimbatore Medical College, Tamilnadu.

\section{BACKGROUND}

ABSTRACT

In India, around $22 \%$ of total reported AIDS cases and 30\% of newer HIV infections are among women. Reproductive tract morbidities are common in HIV-infected women and they are 10 times more likely to have abnormal Pap smears than HIV-negative women. Unlike most other cancers, carcinoma cervix is highly preventable when precursor lesions are detected and treated before they develop into cancer. This study mainly highlights the importance of cervical cytology in HIV-infected women and to increase the awareness of the value of Pap smear as an integral part of preventive care for HIV-infected women.

\section{MATERIALS AND METHODS}

The present study was undertaken in a total of 100 HIV-positive women attending Coimbatore Medical College Hospital over the period of two years. Correlation and statistical data analysis of colposcopic findings, Pap smear findings and CD4 count were studied.

\section{RESULTS}

In the present study, $45 \%$ of women had abnormal Pap smear, which included inflammation 14\%, reactive atypia $6 \%$, various organisms 20\%; and epithelial abnormalities 5\% which included squamous intraepithelial lesions and squamous cell carcinoma. $70.6 \%$ of women with abnormal colposcopic findings had abnormal Pap smear and $18.4 \%$ women with normal cervix had abnormal Pap smear. Abnormal Pap smears were reported in $46.9 \%$ of women with CD4 count $\leq 200$, in $48.9 \%$ of women with CD4 count between 201-500 and in 50\% of women with CD4 count between 501-700. Incidence of abnormal Pap smears increased in HIVinfected women, irrespective of colposcopic findings and CD4 counts.

\section{CONCLUSION}

This study concluded that all HIV-positive women should be regularly screened with Pap smear to diagnose lower genital tract neoplasia at the earliest, regardless of age, colposcopic findings and CD4 counts, so that they can be promptly and effectively treated.

\section{KEYWORDS}

HIV, Pap Smear, Squamous Cell Carcinoma, Squamous Intraepithelial Lesion.

HOW TO CITE THIS ARTICLE: Kavitha M, Pavithra T, Lalitha C. Significance of pap smear in detecting abnormalities of cervix in HIVinfected women. J. Evolution Med. Dent. Sci. 2017;6(95):7036-7039, DOI: 10.14260/jemds/2017/1526

\section{BACKGROUND}

HIV/AIDS pandemic is emerging as one of the most serious health problems of this century and the focus is shifting fast from developed nations to developing countries including India due to its vast population.[1]

In India, around $22 \%$ of total reported AIDS cases and $30 \%$ of newer HIV infections are among women.[2] HIV infection results in progressive depletion of immune system making the host susceptible to various opportunistic infections and other AIDS related malignancies. Though the process cannot be stopped, it can be slowed down, which would improve the quality of life.

Vulvovaginal candidiasis, Cervical dysplasia, Cervical cancer in situ and Pelvic Inflammatory Disease (PID) were added to the revised classification system of HIV infection under category B. ${ }^{[3]}$ Cervical cancer is the second most common cancer among women worldwide with mortality of

'Financial or Other Competing Interest': None.

Submission 30-10-2017, Peer Review 06-12-2017,

Acceptance 12-12-2017, Published 23-12-2017.

Corresponding Author:

Dr. Pavithra T,

BG-6, Krishna Brindavan Apartment,

SNV Garden, Nanjundapuram Road,

Coimbatore-641036, Tamilnadu.

E-mail: drpavithra81@gmail.com

DOI: $10.14260 /$ jemds/2017/1526

\section{(c) (1) $(\Theta$}

2,75,000 deaths each year.[4] Also cervical cancer has an increased occurrence and aggressiveness in HIV-infected women.

It is very important for the HIV-positive women to have regular Pap smear. Pap smear is one of the important screening procedures which was introduced by Dr George Papanicolaou and Traut in 1943 to lower the morbidity and mortality of cervical cancer by its early detection.

\section{MATERIALS AND METHODS}

This analytical study was carried out in the Department of Pathology, Coimbatore Medical College over a period of two years. Ethical clearance was obtained from the ethics committee of Coimbatore Medical College.

A total of one hundred HIV-positive women of who attended STD/Gynaecology Outpatient Clinic were included in this study, after getting informed consent. Strict confidentiality was maintained throughout the study.

A detailed history of the patient was obtained. General examination and pelvic examination were performed. Per speculum examination was performed to assess cervix. The patient was placed in lithotomy position. The Ayre's spatula was introduced through the external os and the squamocolumnar junction was scraped by rotating the spatula to $360^{\circ}$. The scraping was then evenly spread onto a glass slide which was immediately fixed using 95\% isopropyl alcohol and proceeded with Papanicolaou staining. The slides were read 
and analysed according to the Bethesda 2001 reporting guidelines.

\section{RESULTS}

$55 \%$ of women had normal Pap smear and $45 \%$ had abnormal Pap smear. Of these abnormal Pap smears, inflammation was present in $14 \%$ of women, reactive cellular changes in $6 \%$ women and organisms in $20 \%$ women. Low grade squamous intraepithelial lesion (LSIL) was present in $3 \%$ of women and squamous cell carcinoma (SCC) in $2 \%$ women. (Table-1). Maximum incidence of epithelial abnormalities was in the age group of 31-40 years. Two of them had LSIL, while the other two had SCC. One patient in the age group 41-50 years had LSIL. (Table-2).
$70.6 \%$ of women with abnormal colposcopic findings had abnormal Pap smear. Cervical erosion was present in $47 \%$ patients, cervix bleed on touch in $2 \%$ of women. One patient had an irregular growth on cervix. But only $18.4 \%$ women with normal cervix had abnormal Pap smear. (Table-3). This indicated that the relationship between Pap smear results and colposcopic findings is statistically significant. (P value $<0.01$ ).

Abnormal Pap smears were reported in $46.9 \%$ of women with CD4 count $\leq 200$, in $48.9 \%$ of women with CD4 count between 201-500 and in 50\% of women with CD4 count between 501-700. (Table-4). $\mathrm{P}$ value $>0.05$ indicated that the relationship between Pap smear findings and CD4 count was not statistically significant. Hence, it was concluded that Pap smear abnormalities could occur irrespective of CD4 count.

\begin{tabular}{|c|c|c|c|}
\hline Sl. No. & Variables & $\begin{array}{c}\text { No. of Cases } \\
n=100\end{array}$ & $\%$ \\
\hline 1 & $\begin{array}{l}\text { Negative for intraepithelial lesion or malignancy } \\
\quad \text { (NILM) } \\
\text { 1. No inflammation and epithelial abnormality } \\
\text { 2. Inflammation } \\
\text { 3. Reactive cellular changes } \\
\text { 4 Organisms: } \\
\text { - Shift in flora } \\
\text { - Candida } \\
\text { - Herpes simplex virus } \\
\text { - Trichomonas vaginalis } \\
\text { - Atrophic smears }\end{array}$ & $\begin{array}{c}95 \\
52 \\
14 \\
6 \\
8 \\
7 \\
4 \\
1 \\
3 \\
\end{array}$ & $\begin{array}{c}95 \% \\
52 \% \\
14 \% \\
6 \% \\
8 \% \\
7 \% \\
4 \% \\
1 \% \\
3 \% \\
\end{array}$ \\
\hline 2 & $\begin{array}{l}\text { Epithelial abnormalities } \\
\text { LSIL } \\
\text { SCC } \\
\end{array}$ & $\begin{array}{l}3 \\
2\end{array}$ & $\begin{array}{l}3 \% \\
2 \%\end{array}$ \\
\hline
\end{tabular}

(LSIL-low grade squamous intraepithelial lesion, SCC-squamous cell carcinoma).

\begin{tabular}{|c|c|c|c|c|c|}
\hline \multirow{2}{*}{ Sl. No. } & \multirow{2}{*}{ Age in Years } & Total No. of Women & \multicolumn{2}{|c|}{ No. of Women with Epithelial Abnormalities } \\
\cline { 3 - 5 } & & $\mathbf{n = 1 0 0}$ & LSIL $\mathbf{n = 3}$ & SCC $\mathbf{n = 2}$ & Total $\mathbf{n = 5}$ \\
\hline 1 & $\leq 30$ & $31(31 \%)$ & - & - & - \\
\hline 2 & $31-40$ & $52(52 \%)$ & $2(3.85 \%)$ & $2(3.85 \%)$ & $4(7.70 \%)$ \\
\hline 3 & $41-50 \quad$ Table 2. Comparison of Age and Epithelial Abnormalities & - & $1(5.88 \%)$ \\
\hline \multicolumn{5}{|r}{} \\
\hline
\end{tabular}

(LSIL-low grade squamous intraepithelial lesion, SCC-squamous cell carcinoma)

\begin{tabular}{|c|c|c|c|c|}
\hline \multirow{2}{*}{$\begin{array}{c}\text { Sl. } \\
\text { No. }\end{array}$} & $\begin{array}{c}\text { Speculum } \\
\text { Findings }\end{array}$ & $\begin{array}{c}\text { Normal } \\
\mathbf{n = 5 5}\end{array}$ & $\begin{array}{c}\text { Abnormal } \\
\mathbf{n = 4 5}\end{array}$ & Total \\
\hline 1 & Normal Cervix & $40(81.6 \%)$ & $9(18.4 \%)$ & 49 \\
\hline 2 & $\begin{array}{c}\text { Abnormal } \\
\text { Cervix }\end{array}$ & $15(29.4 \%)$ & $36(70.6 \%)$ & 51 \\
\hline \multicolumn{4}{|c|}{ Table 3. Relationship between Pap Smear Results and } \\
Speculum Findings \\
\hline
\end{tabular}

\begin{tabular}{|c|c|c|c|c|}
\hline \multirow{2}{*}{ Sl. No. } & \multirow{2}{*}{$\begin{array}{c}\text { CD4 } \\
\text { Count }\end{array}$} & $\begin{array}{c}\text { Normal } \\
\mathbf{n = 5 5}\end{array}$ & $\begin{array}{c}\text { Abnormal } \\
\mathbf{n = 4 5}\end{array}$ & $\begin{array}{c}\text { Total } \\
\mathbf{n = 1 0 0}\end{array}$ \\
\cline { 3 - 5 } & $\leq 200$ & $17(53.1 \%)$ & $15(46.9 \%)$ & 32 \\
\hline 1 & $201-500$ & $23(51.1 \%)$ & $22(48.9 \%)$ & 45 \\
\hline 2 & $501-700$ & $7(50 \%)$ & $7(50 \%)$ & 14 \\
\hline 3 & $>700$ & $8(88.9)$ & $1(11.1 \%)$ & 9 \\
\hline 4 & \multicolumn{5}{|c|}{ CD4 Count } \\
\hline \multicolumn{5}{|c|}{ Table 4. Relationship between Pap Smear Findings and } \\
\hline
\end{tabular}

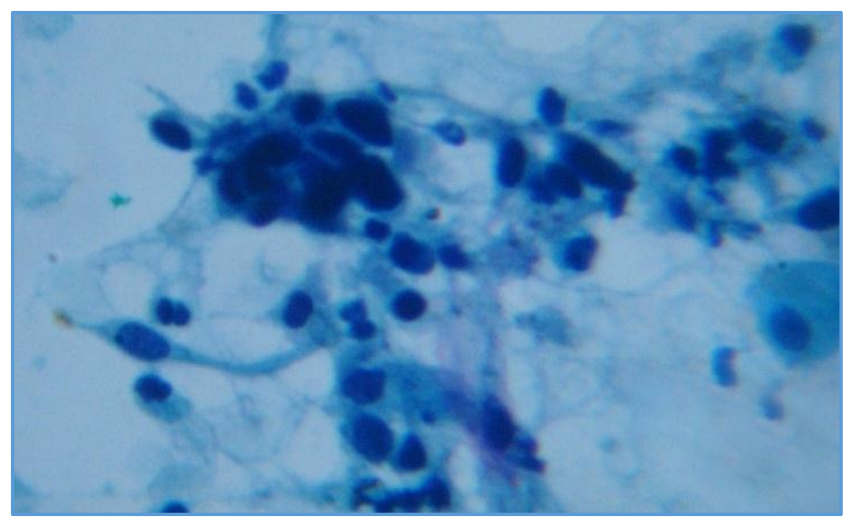

Figure 1. Squamous Cell Carcinoma Cells showing Marked Nuclear Pleomorphism and Atypia(Papanicolaou, 40x) 


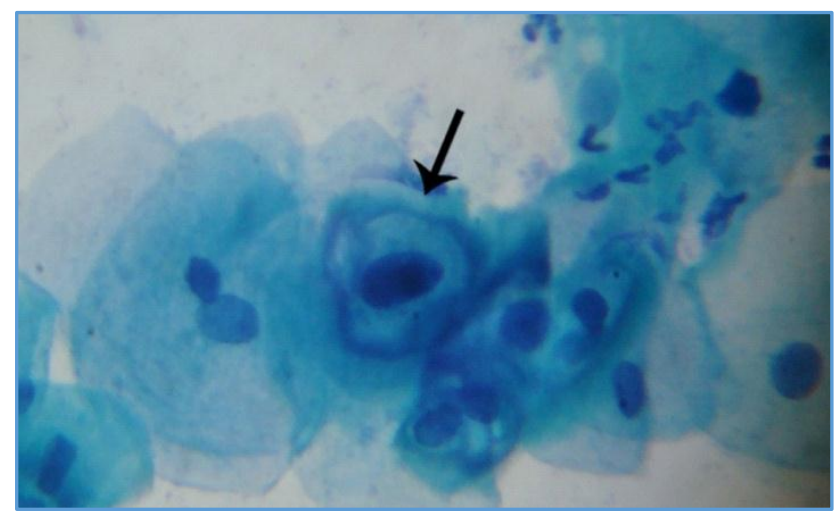

Figure 2. Cellular changes Consistent with HPV-associated LSIL: Koilocytosis, Nuclear Abnormality (Papanicolaou, 40x)

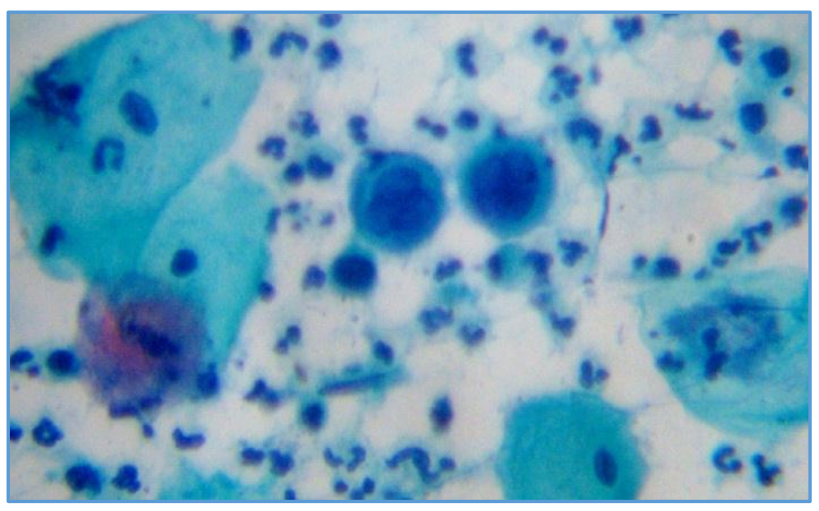

Figure 3. Cellular changes Consistent with Herpes Simplex Virus: Ground Glass Nuclei, Multinucleation (Papanicolaou, 40x)

\section{DISCUSSION}

In India, around 2.3 million people are living with HIV. Of these, an estimated 39\% are females.[5] HIV-infected women are more susceptible for reproductive tract morbidities and hence, all HIV-positive women must be screened periodically by Pap smear for evidence of genital tract involvement, so that they can be promptly and effectively treated.[6] Incidence of abnormal Pap smears is higher in HIV-infected women. An abnormal Pap smear can indicate inflammation, infection, dysplasia or cancer.

Exfoliative cervicovaginal cytology has been regarded as the gold standard for cervical screening programs. The availability of cervical cytology to screen for cervical cancer often permits diagnosis at the preinvasive stage, when treatment can almost always prevent progression to invasive cancer. For this reason, screening for cervical cancer is important in HIV-infected women since the incidence of cervical intraepithelial neoplasia and cancer cervix are four to five times higher in HIV-positive women. Also women with HIV and cervical cancer tend to be younger than HIV-negative women with cervical cancer.

HIV-infected women are 10 times more likely to have abnormal Pap smears than HIV-negative women. ${ }^{[7]}$ Hence CDC recommends, all HIV-positive women should have a complete gynaecological examination, including a Pap smear, when they are first diagnosed or when they first seek prenatal care.[8]

In the present study, $52 \%$ of women were from the age group of 31-40 years. Maximum incidence of abnormal Pap smear was between $31-40$ years. Only $29.4 \%$ of women between 41-50 years had abnormal Pap smear (Table-2). P value $>0.05$ indicated that the relationship between age and Pap smear findings was statistically not significant. Hence, it was concluded that Pap smear abnormalities could occur irrespective of age group.

$45.9 \%$ women from middle socioeconomic status and 45.8\% from lower socioeconomic status had abnormal Pap smear. None of the women from high socioeconomic status had abnormal Pap smear. $P$ value $>0.05$ indicated that the relationship between Pap smear and socioeconomic status was statistically not significant. Hence, it was concluded that Pap smear abnormalities could occur irrespective of socioeconomic status.

$65 \%$ of women had gynaecological complaints like vaginal discharge, itching, ulcer and irregular bleeding and 35\% of women were asymptomatic. Most common presenting complaint was discharge per vaginum (55\%).

Minkoff et al (1999) had a similar observation in which $46.9 \%$ of 262 HIV-infected women had at least one gynaecological problem with serial assessment. [9] But this is less than the observations made by Frankel et al (1997), in which $83 \%$ of HIV-positive women had gynaecological problems when evaluated.[10]

These results indicate that gynaecologic problems are common among HIV-positive women and are frequently present at the time of initial presentation for evaluation and care.

$70.6 \%$ of women with abnormal cervical findings like cervical erosion and growth on colposcopy had abnormal Pap smear. But only $18.4 \%$ women with normal cervix had abnormal Pap smear. $\mathrm{P}$ value $<0.01$ indicated that the relationship between Pap smear results and speculum findings was statistically significant. (Table-3).

In the present study, $45 \%$ of women had abnormal Pap smear, which included inflammation $14 \%$, reactive atypia $6 \%$, various organisms $20 \%$ and epithelial abnormalities 5\%. (Fig$1,2,3)$. Maiman et al (1998) observed that 30-60\% of Pap smears exhibited cytological abnormalities and $15-40 \%$ had evidence of dysplasia.[11] Mojgan et al (2015) observed that $20.3 \%$ of HIV patients had abnormal Pap smears and $10.7 \%$ of them had abnormal colposcopy.[12]

It was observed that the maximum incidence of epithelial abnormalities was between the age group of 31-40 years. Both the patients with squamous cell carcinoma were under the age of 40 years.

This observation was similar to that of Lomalisa et al (2000)[13], who found that in HIV-positive women cervical cancer presented between the ages of 35 and 40, which is 10 15 years earlier than expected in HIV-negative women. These results showed that women with HIV and cervical cancer tend to be younger than HIV-negative women with cervical cancer.

All women with epithelial abnormalities had CD4 count below 500. Two of them had SCC and one of them had LSIL. Mean CD4 count of women with epithelial abnormalities was 297.8 and mean CD4 count of women with SCC was 422.5. P value $>0.05$ indicated that the relationship between Pap smear findings and CD 4 count was not statistically significant. Hence, it was concluded that Pap smear abnormalities could occur irrespective of CD4 count. (Table-4).

This was similar to that of Mbulaiteye et al, (2003) who found that cervical cancer was not related to CD4 count.[14] But it was in contrast with the study of Lomalisa et al (2000) who 
found that mean CD 4 cell count was 443 cells $/ \mathrm{mm}^{3}$ at the time of diagnosis of cervical cancer in women with HIV.[13] Both frequency and severity of abnormal Pap smears and histologically documented dysplasia increase with declining CD4 counts, this was observed by Davis et al (2001).[15] Umaru et al (2016) observed in their study that as the individual immunity improves with higher CD4 count, the risk of abnormal Pap smear reduces. [16]

US Public Health Service (USPHS)/Infectious Diseases Society of America (IDSA) 2001 recommends that HIVinfected women should have a complete gynaecologic evaluation, including a Pap smear and pelvic exam, as part of their initial evaluation. A Pap smear should be obtained twice in the first year after diagnosis of HIV infection. If these results are normal, annual examinations are then indicated.

More frequent Pap smears should be considered in those HIV-infected women with previous abnormal Pap smear, with HPV infection and after treatment for cervical dysplasia in women with symptomatic HIV infection including CD4 counts $<200 / \mathrm{mm}^{3}$.

\section{CONCLUSION}

Pap smear screening of HIV-positive women has demonstrated a four to tenfold increase in abnormal results compared to HIV-negative women. It is hoped that such screening appreciably decreases the potential for cervical cancer in HIV-positive women. Hence, our study concluded that all HIV-positive women should be regularly followed up with Pap smear for evidence of lower genital tract neoplasia, regardless of age, gynaecological symptoms, colposcopic findings or CD4 count.

\section{REFERENCES}

[1] Gourevitch MN. The epidemiology of HIV and AIDS. Current trends. Med Clin North Am 1996;80(6):122338.

[2] Sande MA, Volberding PA. The medical management of AIDS. $5^{\text {th }}$ edn. Philadelphia: WB Saunders 1999.

[3] 1993 revised classification system for HIV infection and expanded surveillance case definition for AIDS among adolescents and adults. JAMA 1993;269(4):460.

[4] de Freitas AC, Coimbra EC, Mda LC. Molecular targets of HPV oncoproteins: potential biomarkers for cervical carcinogenesis. Biochemica et Biophysica Acta (BBA)Reviews on cancer 2014;1845(2):91-103.
[5] World Health Organization 2005, India: summary country profile for HIV/AIDS treatment scale-up'. May 26, 2010.

[6] Mehta V, Vasanth V, Balachandran C. Pap smear. Indian J Dermatol Venereo Leprol 2009;75(2):214-6.

[7] Berak JS. Novak's text book of gynecology. 13 th edn. Williams and Wilkins 2000;1199-211.

[8] CDC. Morbidity and Mortality Weekly Report 1995;44(RR-8) 22-3.

[9] Minkoff HL, Eisenberger-Matityahu D, Feldman J, et al. Prevalence and incidence of gynecologic disorders among women infected with human immunodeficiency virus. Am J Obstet Gynecol 1999;180(4):824-36.

[10] Frankel RE, Selwyn PA, Mezger J, et al. High prevalence of gynecologic disease among hospitalized women with human immunodeficiency virus infection. Clin Infect Dis 1997;25(3):706-12.

[11] Maiman M. Management of cervical neoploasia in human immunodeficiency virus-infected women. J Natl Cancer Inst Monogr 1998;23:43-9.

[12] Karimi-Zarchi M, Zanbagh L, Shafii A, et al. Comparison of Pap smear and colposcopy in screening for cervical cancer in patients with secondary immunodeficiency. Electron Physician 2015;7(7):1542-8.

[13] Lomalisa P, Smith T, Guidozzi F. Human immunodeficiency virus infection and invasive cervical cancer in South Africa. Gynecol Oncol 2000;77(3):4603.

[14] Mbulaiteye SM, Biggar RJ, Goedert JJ, et al. Immune deficiency and risk for malignancy among persons with AIDS. J Acquir Immune Defic Syndr 2003;32(5):527-33.

[15] Davis AT, Chakraborty H, Flowers L, et al. Cervical dysplasia in women infected with the human immunodeficiency virus (HIV): a correlation with HIV viral load and CD4+ count. Gynecol Oncol 2001;80(3): 350-4.

[16] Umaru I, Calvin C, Bala A, et al. Correlates and risk factors for abnormal Papanicolaou smear among HIV infected and HIV non infected women in North eastern Nigeria. African Journal of AIDS and HIV Research 2016;4(2):196-200. 